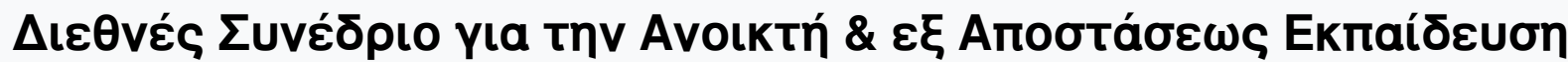

Tóp. 10, Ap. 3A (2019)

\section{ПPAKTIKA}

$10^{C}$ EYNEAPIO TIA THN ANCIKTH \& E AחCETALERI EKMAIAEYLH

를

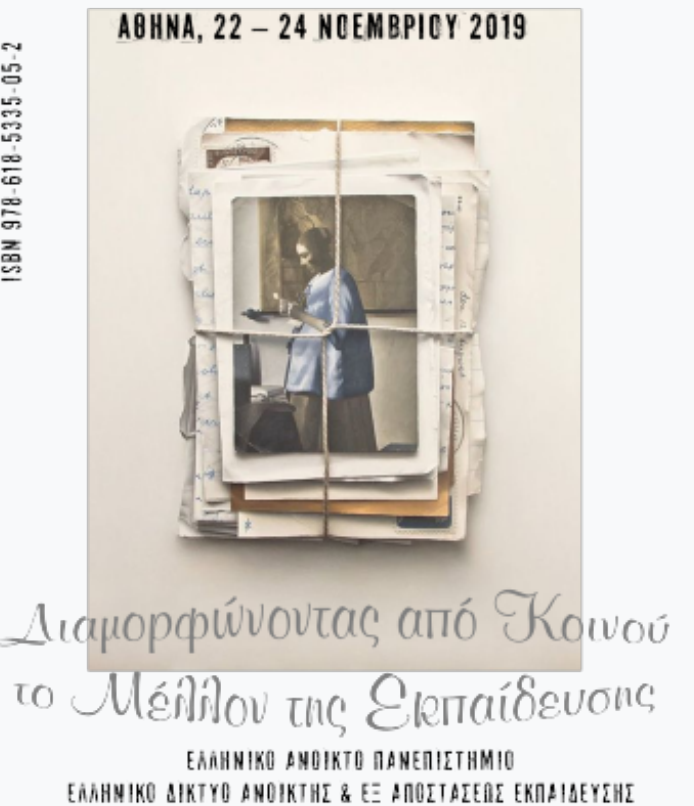

Greek as Second Language: Designing tailor made teaching material for teenagers with refugee/migrant background

\section{Athanasia Angeli}

doi: $10.12681 /$ icodl.2354

\section{TOMOL 3, MEPOLA $(a)$}




\title{
Greek as Second Language: Designing tailor made teaching material for teenagers with refugee/migrant background
}

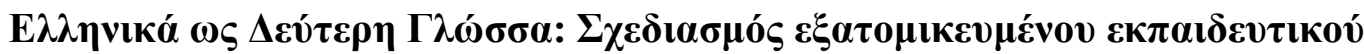

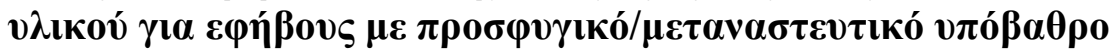

\author{
Angeli Athanasia \\ M.Ed., PhD candidate \\ Hellenic Open University \\ 8aggeli@gmail.com
}

\begin{abstract}
The aim of this paper is to describe all faces of designing educational material tailored to the communicative needs of a teenager with refugee/migrant background, in order to assist her/his learning Greek as second language. Hence, this essay has two main parts: In the first part can be found the theoretical background of the importance of the learners' sociolinguistic profile as a means of identifying their personalized educational needs and the particular role of their parents as an influencing factor, along with the preconditions of an effectively designed educational material for second language learners. In the second part, a particular case is presented: First, the research data of two semistructured interviews and identity texts and the inferred sociolinguistic profile of a 14 year old refugee girl, attending the Reception Class (ZEP I) in a Greek public High School in Athens. Then, the educational material produced for a tailor-made one hour lesson, along with the reasoning of the selected content and language activities. Finally, some generalizing suggestions for further use of this educational research procedure into language teaching towards multi-lingualizing the classroom.
\end{abstract}

Key-words: Second Language Teaching material, Greek as L2, Greek Language Learning for Migrants and Refugees, Sociolinguistic profile

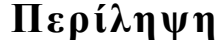

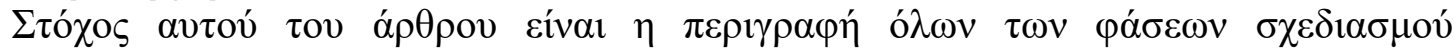

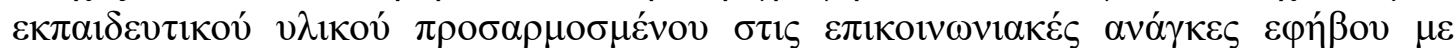

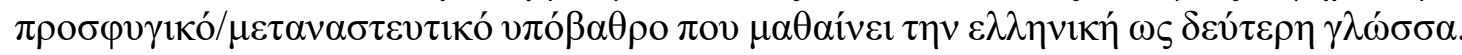

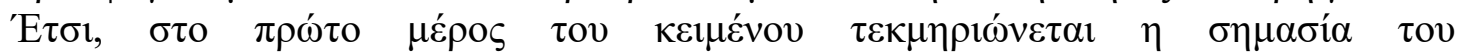

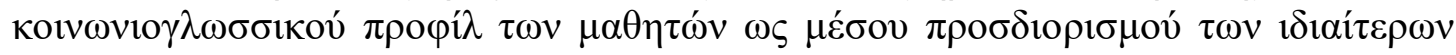

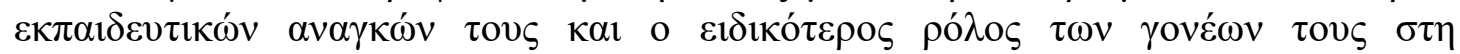

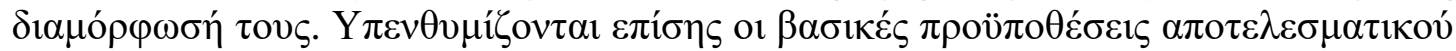

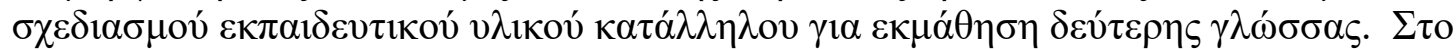

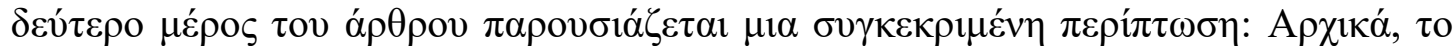

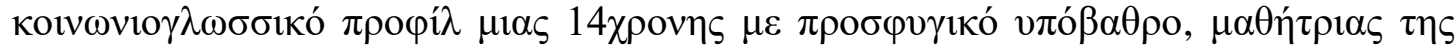

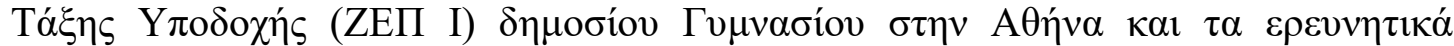

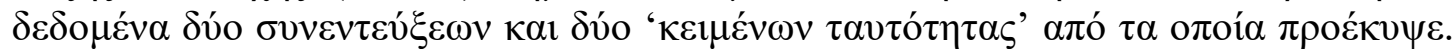

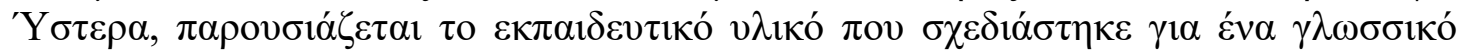

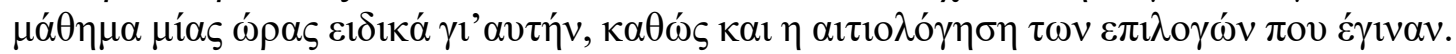

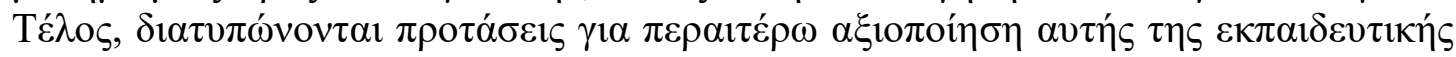

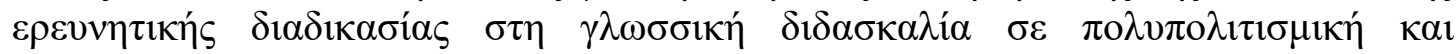
$\pi \circ \lambda \hat{\gamma} \gamma \omega \sigma \sigma \eta \tau \alpha \dot{\xi} \eta$. 


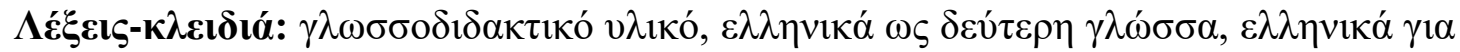

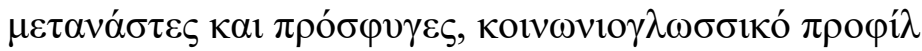

\section{Introduction}

Worldwide, the consequences of globalization and particularly the recent wide migratory and refugee flows have highlighted new challenges, humanitarian, political and educational (Appadurai, 1990; Dryden-Peterson, 2015). Additionally, education in this context remains an area of economic, social, and political inequality (Bloch \& Hirsch, 2017), used as a policy tool for pursuing assimilation, integration, or multiculturalism (Matthews, 2008).

Especially with regard to migrant/refugee children, given that in their turbulent lives education is a basic stabilizing factor, but also a guarantee that they will actually become "more than they -already- are" affirming their "linguistic, cultural, intellectual talents and accomplishments" (Chumak-Horbatsch, 2012, p.xiii), the need for inclusive education in a safe supportive environment (Engelbrecht, Savolainen, Nel, Koskela, \& Okkolin, 2017) is evident. Particularly in Greece, where thousands of migrant and refugee children (Gkaintartzi, Kiliari, \& Tsokalidou, 2016; S.C.S.R.C., 2017) form a highly multilingual educational context, where people constantly shift between languages, translanguaging and negotiating their identities (Cummins, 2001), bi/multilingual education is obviously needed. Building on their existing knowledge and language resources and solidifying their sense of identity and personhood can improve their academic performance, enhancing their participation both in class and in a democratic, inclusive, equal society (Hornberger, 2004).

Of course, these acknowledgments consequently affect educators' role, who have to be teachers, treating their bi/multiliterate learners' developing communication skills in ways "socioculturally and sociopolitically contextualized, locally and multiply inclusive, enquiry-based and dynamically negotiated", researchers, who "reflect critically on the contexts and content of their teaching", reveal and use the communicative repertoires ("media") brought to school by students "as resources for their language \& literacy development", and planners who create "more equitable educational policies and practices for linguistically diverse students" (Hornberger, 2004, p.168).

This is the purpose of this study: to follow all the necessary steps in order to design and present the language teaching material appropriate for a mini course ( 1 hour) for an adolescent student of the Reception Class (ZEP I) of a public High School in Athens, Greece.

\section{Literature review}

Second language courses for refugee/migrant children in the host country need to provide them with a variety of meaningful learning experiences, hence, to be differentiated and individualized, in order to meet their particular learning needs (Kaneva, 2012). A substantial tool to identify and understand the linguistic realities of these children and their bi/multilingual worlds is their sociolinguistic profile, which includes information about their personal history, which -although often escapes the teachers (Matthews, 2008; Dryden-Peterson,2015)- influences their literacy and linguistic experiences, their language choice and practices (e.g. translanguaging), their skills, strengths, expectations, and challenges.

Thus, children's sociolinguistic profile depends on their past (racial, ethnic, linguistic, religious, regional, political and socioeconomic backgrounds, refugee trajectories, pre- 
/post-displacement experiences, e.g. racialization, persecution, torture, trauma, resilience, acculturation, and assimilation), present (personal characteristics, family life, migrant and socioeconomic status, community and social networks and transnational activities) and desirable future. Furthermore, it contains information about their preand post-migration educational experiences: lack of or limited literacy in mother tongue and unfamiliarity with specific literate practices, lack of or interrupted formal schooling, different language competency levels and learning styles, and instruction quality, usually, poor due to inadequate financial support, lack of appropriate specialized training of teachers, and teacher-centered pedagogy, large classes or placement into classes with younger children (Dryden-Peterson, 2015; Matthews, 2008; Bloch \& Hirsch, 2017; Chumak-Horbatsch, 2012).

However, within an inclusive and holistic approach (Block, Cross, Riggs, \& Gibbs, 2014), children's educational and, in particular, language learning needs are differentiated also by their parents/guardians influence. Their own educational level and the degree of their knowledge of the school's predominant language, their religious/cultural values and assumptions for their children's education (e.g. lack of engagement or even exclusion from school), and their specific aspirations for them (e.g. professional stereotypes or girls' education) (Dryden-Peterson, 2015), can be reinforcing factors or obstacles to the support they can provide to their children's homework or communication with the school context (Androulakis, Gkaintartzi, Kitsiou, \& Tsioli, 2016). Finally, the mandatory frequent movement, as well as the parents' intention for final relocation in another host country than that of the school, may well influence the motivation and stability of children's participation in the current language learning process (S.C.S.R.C., 2017).

Hence, in order to provide appropriate and effective language instruction, a thorough initial assessment is necessary, including (semi-)structured initial interviews, providing all aforementioned information and establishing a communicational bridge between the educational context and the child and parents, probably with the necessary support of an interpreter. Besides, they may also be used as an initial assessment tool of child's oral language skills (Ontario Ministry of Education, 2008).

Additionally, substantial source of all these factors affecting children's sociolinguistic profile and language learning needs, and basic tool for their empowerment, providing them voice, are "Identity Texts" (Kompiadou \& Tsokalidou, 2014), i.e. the "written, spoken, signed, visual, musical, dramatic, or combinations in multimodal form" or digital "products of students' creative work or performances carried out within the pedagogical space orchestrated by the classroom teacher" (Cummins, et al., 2005). Given that "students invest their identities in the creation of these texts", they hold "a mirror up to students in which their identities are reflected back in a positive light" and affirmed (Cummins \& Early, 2011, p.3).

This language needs analysis (Ontario Ministry of Education, 2008) also includes assessment of all 3 facets of children's "language proficiency" according to Cummins (2001, p.65): (a)'Conversational fluency', necessary for non-formal communication, in face-to-face situations, where simple grammatical structures and high frequency vocabulary is used, and contextual and interpersonal cues support the communication meaning, (b) 'Discrete language skills', involving specific phonological and grammatical knowledge of "rule-governed aspects of language" (Cummins, 2008, p.76), presupposing not only direct instruction, but also practice, both formal and informal, and (c)Academic language proficiency, which is more complex and cognitively more demanding due to the higher order thinking skills associated with it and, usually, has 
no familiarity to bi/multilingual pupils' everyday life and language, is impersonal, more abstract and more technical, i.e. 'context reduced' (Cummins, 2001, p.67).

Teachers considering all these factors have to set the relevant educational goals and choose the appropriate teaching practices, which in the case of beginners migrant/refugees have to be gradually moving from 'undemanding' in the beginning, to more demanding and context-embedded later (from Quadrant A to Quadrant B), (Cummins, 2001, p.67), using multimedia, visual and language stimuli, yet, always supporting students' cognitive development based on their identity investment and respecting their bi/multilingual repertoire (Cummins, 2001; Ontario Ministry of Education, 2008).

Important role in this differentiated, individualized, language teaching, reflecting teacher's pedagogic attitudes and choices, has the educational material, which obviously has to be also situated, i.e. contextualized, considering the educational context and the curriculum, the available resources and the relevant facilities, the teacher's competences and most of all, the particular learner(s)'s individual needs (Howard \& Major, 2004). Admitting that one-size-fits-all is inadequate, educators usually produce their own material, often adapting commercial course books or synthesizing more of them, transforming them under their personal pedagogy. Nevertheless, this tailor-made material has to fulfill certain preconditions: it has to be contextualized, authentic, flexible, and attractive, to stimulate interaction, encouraging learners to develop learning skills and strategies, linking coherently to further progression of language skills, to focus on form simultaneously focusing on function, offering opportunities for integrated language use (Howard \& Major, 2004).

\section{Research}

\subsection{Methodology}

The main research question addressed in this study was: How can an adolescent migrant/refugee's sociolinguistic profile and her/his respectful second language learning needs be integrated in a tailor-made language teaching material towards "multi-lingualizing" the classroom?

Thus, the main objective was to draw the sociolinguistic profile and explore the language and communicative needs of an adolescent refugee girl, F.A., student of the Reception Class I facilitated in 2018 in a public High School of Athens, in order to design a 1-hour mini-language lesson intervention appropriate for her, creating the respective educational material.

For the purposes of this study, qualitative research methods were chosen. Aiming to determine her sociolinguistic profile, information was collected from (1)two identity texts of F.A. (a)on the $14^{\text {th }}$ day of her Greek language lessons (27.4.2018), and (b)after the end of the school year (18.6.2018), and (2)two transcribed semi-structured interviews (Taylor, Bogdan, \& DeVault, 2015), (a)by her (18.6.2018) and (b)her father (M.A.) (13.6.2018), both with the support of a cultural mediator, who was provided by the NGO which shelters the girl's family, after hers and her father's consent. The Consent Form was also translated by the cultural mediator and signed by the parent. Qualitative thematic analysis was carried out on the collected data (Braun, \& Clarke, 2006). 


\subsection{Data analysis}

\subsubsection{Interviews}

At the time, F.A. from Bagdad, Iraq, was 14 years old. Her family was in Greece almost one year. According to both aforementioned interviews and focusing mostly on language and educational experiences:

\subsection{1.a.Family and personal educational background}

F.A's mother has attended 2 classes in High School. Her father has finished it. He used to be a carpenter. F.A. has 2 younger brothers, 12 and 6 years old. During their stay in Greece her brothers do not attend Greek formal education, due to bureaucratic difficulties, according to their supporting NGO. F.A. was enrolled in the $1^{\text {st }}$ grade of Iraqi High School when they left Bagdad and before the Reception Class was attending (for 2 months) only English language lessons in the learning center of another NGO. She has always been a 'good learner' according both herself and her father, who attributes that accomplishment (a)to the time spent and the critical thinking practices by the parents teaching their children and (b)to their expectations for them:

"I try to explain to her that a doctor is not just someone who knows things, but someone who comprehends them"...

"What we try to teach our children is not to be afraid to make mistakes.".

F.A. adds motivation as a trigger for being a 'good learner': "because I think that learning languages is something useful".

\subsection{1.b. Home language(s) and language use}

F.A's family speaks Arabic at home and seems to have very few opportunities to use it outdoors, due to a deliberately chosen lack of language community relations. They also practice Finnish, which they have been taught in school or/and in informal learning programmes (for the adults) during their one year stay in Finland, 3 years ago. F.A. and her father highly respect the Finnish educational system, due to the integration of technology devices and applications. Now they teach each other English through mobile phones. Lately, they also learn Greek at home with the help of F.A.

Her father does not consider that her L1 will ever be in danger of loss, even if she learned "20 languages", which is his aspiration for her, adopted by her too:

"Generally, I like to learn languages, but what I dream is to travel and .....to be able to learn each country's language ...".

F.A. considers the monoglossic approach of the Finnish language program, excluding her home language, very effective:

"... they also avoided translating in our mother tongue, in order to learn faster the words in Finnish".

On the other hand, in the Greek High School she constantly translanguages with her peers, using Greek, English and Arabic, teaching her mates her home language. She hasn't got school friends, "yet", though.

She self-evaluates her Greek language competency as such:

"When I hear them I understand what they say, although they speak Greek too. When I want to say something and I don't know the word, English comes up".

\subsection{1.c.Interests}

Apart from her educational activities, F.A. visits with her family parks and hills in Athens and goes shopping. At home she likes to draw and watch videos in You-tube, mostly in English. 


\subsubsection{Identity Texts}

Based on the Identity Text 2 (Figure-1) composed the same day with F.A.'s interview (18.6.18) as a preliminary activity for her own "dual language book" (Cummins et al.2005, p.6), finally meant to be completed at home (due to time limitations deriving from F.A.'s other obligations that day), all elements of her identity mentioned in her interview can be confirmed, written in Arabic and translated with the help of the cultural mediator.

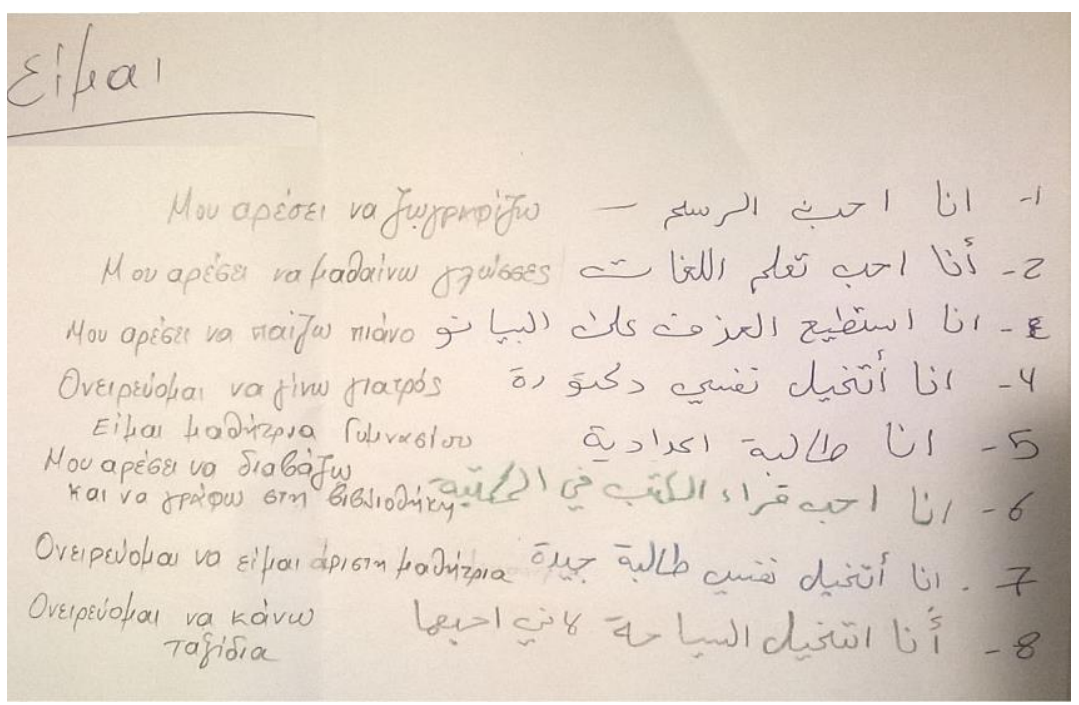

Figure 1. Identity Text-2

For the multimodal Identity Text-1 (Figure-2) (composed during a class activity, and hence with different original educational goals), F.A. used Arabic and English and three

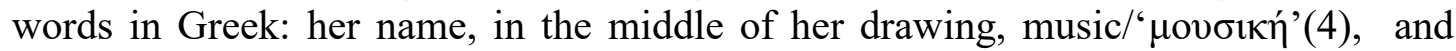

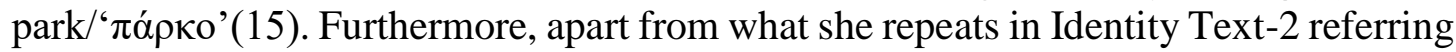
to her academic life $(5,8,10$, plus her compliment to her teacher,14), F.A. mentions her family (7) and emphasizes her desire to have new friends (11 \& 12) along with her special bond with a new school friend, Fatima, who -at the time- had just moved to Germany, though (6). She expresses with sketches and words her love for travelling (2, 5), music (4) and dancing (13) (watching her Greek peers preparing a school celebration, at the time). Finally, she draws a white heart 'waiting' (1) and she is referring to her 'love'(2). Generally, she has included 4 hearts $(1,2,7,12)$ in her Identity Text-1.

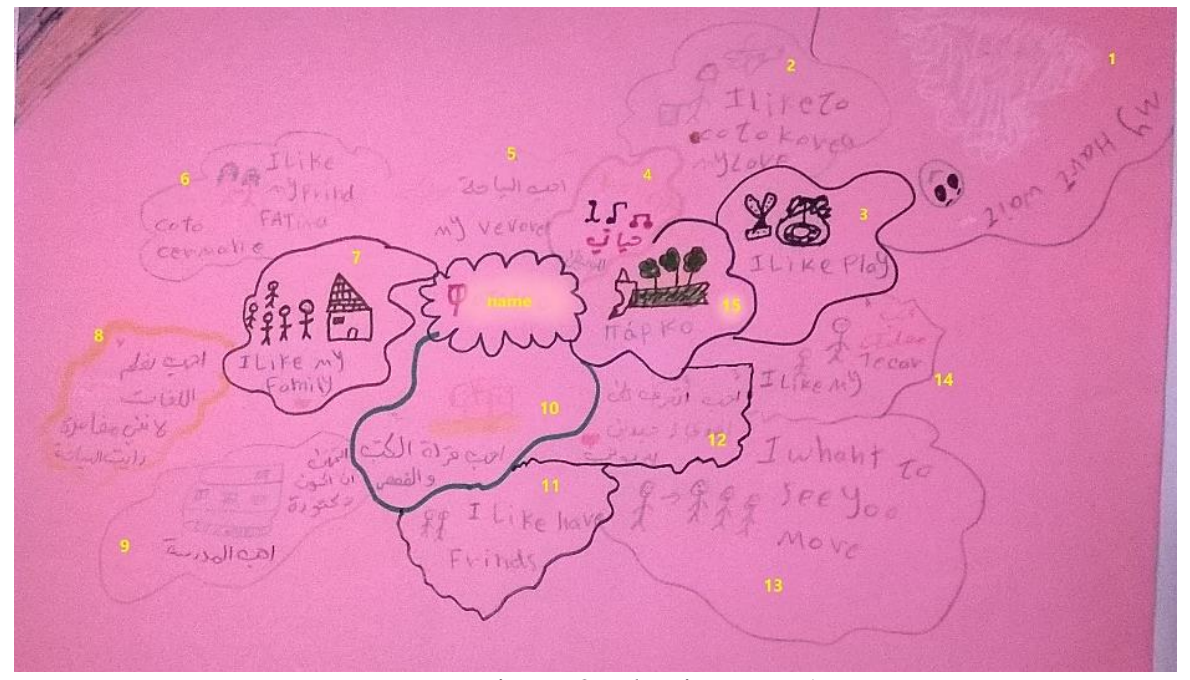

Figure 2. Identity Text-1 
1. My hart wait.

2. I like to co to Korea my love

3. I like play

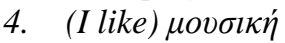

5. (I like to travel) my vevoret

6. I like my frind Fatima co to cermane

7. I like my family
8. I like to learn things. I want friends

9. $\quad . .$.

10. (I like read and write, and stories)

11. I like have frinds

12. (I like to have many good new friends)

13. I whant to see yoo move

14. I like my tecar

\subsubsection{Sociolinguistic profile}

Based on collected data: F.A. is a refugee adolescent girl. Her home language is Arabic. She is also, according to herself, a Finnish and English speaker. Her Greek language skills (which is the target language of this study) are all very poor. She is supported by her previous academic accomplishments and her positive attitude towards education and language learning. Her family shares this attitude and has big expectations of her professional, academic and language future. Although she seems to adopt theoretically the monoglossic approach of the Finnish -and Greek- educational system, she translanguages at school with her peers and during the Greek language lesson. She has not many opportunities to use her language repertoire out of school, beyond her family context. She uses digital devices, like all adolescents today, as a means of social relationships and educational tool. Her communicative domains refer to school, music, travelling, dancing, friends and feelings (love). Obviously, even if she bears many similarities to adolescent girls all over the world, her multiple identities and her preand post- displacement experiences make her unique.

\subsection{Syllabus development/Second Language Learning Material}

In this particular study, a mini-language lesson (1 hour) was designed in the context of communicative language teaching approach and content-based instruction (Rodgers, 2009) through a critical literacy intervention, affirming the student's identity and encouraging her self-evaluation and reflection on experiences and beliefs (Cummins, 2001). Considering the specific curriculum for the Reception Classes (YPETH, 2018), and respecting F.A.'s aforementioned sociolinguistic profile, a 6-page work-sheet was produced (Figures 3,4,5), combining transformed existing educational material (Antoniou, \& Detsoudi, 2004) and original teacher's choices.

The topic of 'feelings' -with the title "Niotho" (I feel...)- was chosen as one of the main issues highlighted in the results of this research, and thus estimated as a meaningful subject, increasing F.A.'s cognitive engagement and enhancing her emotional awareness, hence supporting her academic progress (Cummins, 2009).

Due to F.A.'s familiarity to multimedia and considering the well-known advantages of video as educational tool, particularly in second language teaching (Angeli,2016; 2017), a short part (00.00-01.30) of a Greek song video, accessible on the internet, with the title 'Kafes me gala' (Lyra, 1993) and subject of 'what I love among everyday activities and trivial things', was chosen. This authentic oral text could activate her prior knowledge, allowing F.A. to get acquainted with the natural way native speakers communicate and to approach pictures of everyday life in Greece. Its vocabulary was suitable for her language skills and age and being without visual distractions, which might have complicated the information input, it was appropriate for Cummins's (2001, p.67) Quadrant A activities. 


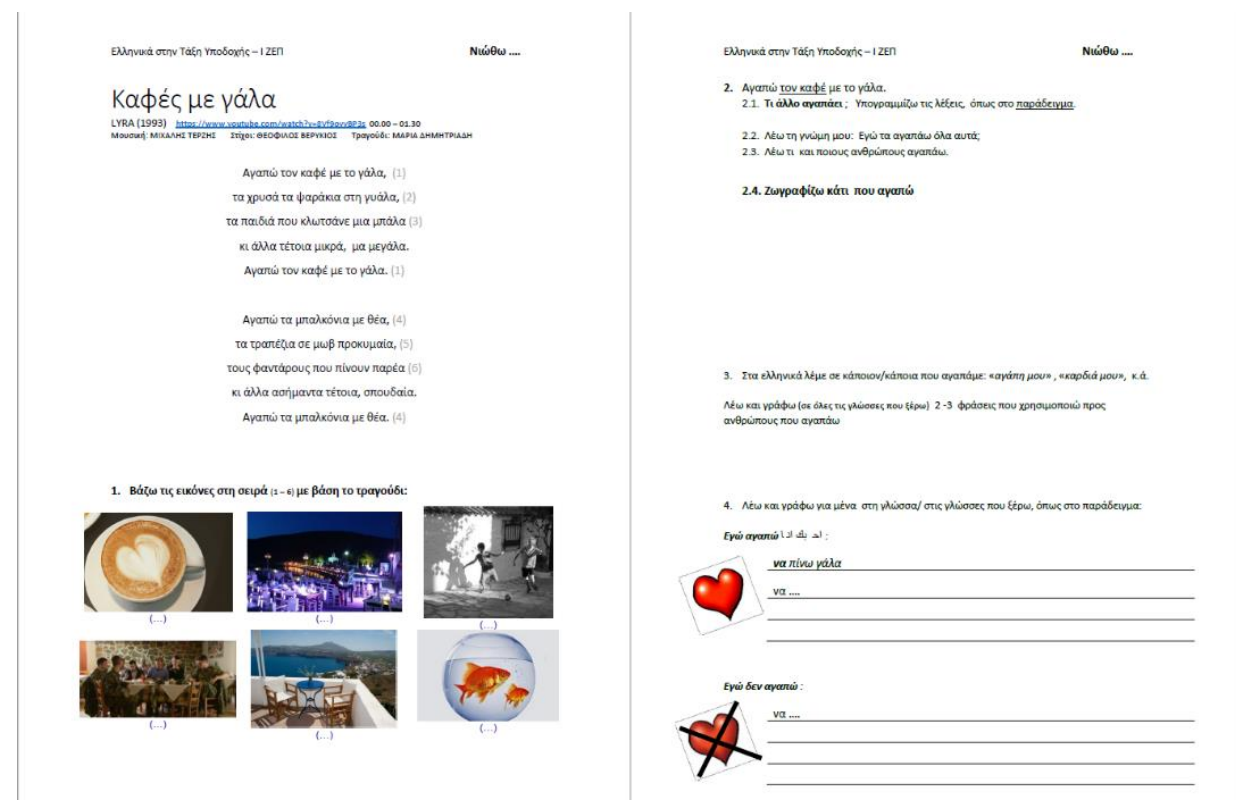

Figure 3. Educational Material, p.1-2. (Activities 1-4)

Authentic tasks, were also preferred, promoting practicing language behaviours necessary in and out of the classroom (e.g. activity 2.2., 2.3., 3., 7.) (Figures 3,4), stimulating language interaction, moving gradually to Cummins's Quadrant B activities. Willing to encourage development of all four language skills, activities for listening (1.) and reading comprehension $(2.1 ., 5.1,8$.$) , production of oral (2.2,2.3,3,4,5.2)$ and written $(4,6,7,8,9)$ text were included (Figures 3,4,5).

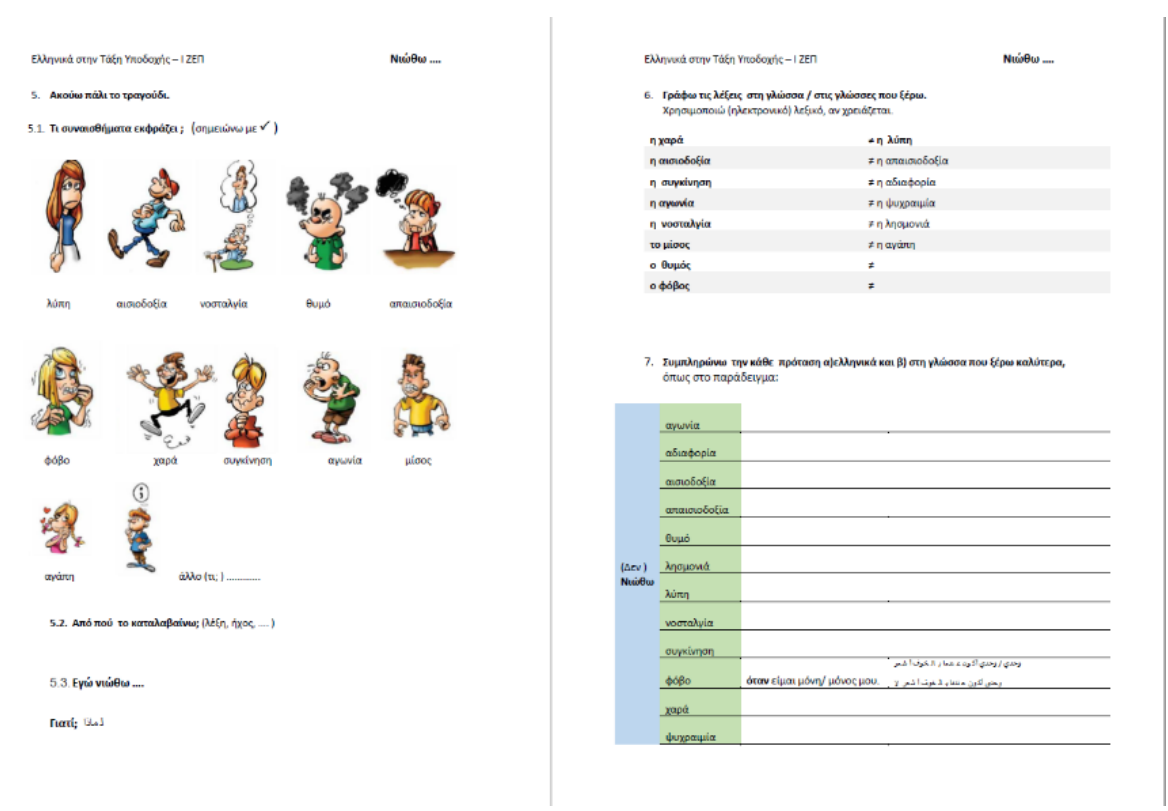

Figure 4. Educational Material, p.p.3-4. (Activities 5-7)

At the same time, important was the parallel emphasis on language function and form (4.,6.,7.,8.,9.), offering opportunities for metalinguistic awareness, e.g. comparing types of the same language or through her whole linguistic repertoire (6.,7.,8.) (Figures $3,4,5)$. Hence, additionally, translanguaging was legitimized and enhanced, facilitating the "flow of knowledge, ideas, and feelings from one domain to another and across languages" (Cummins, et.al., 2005, p.8). 

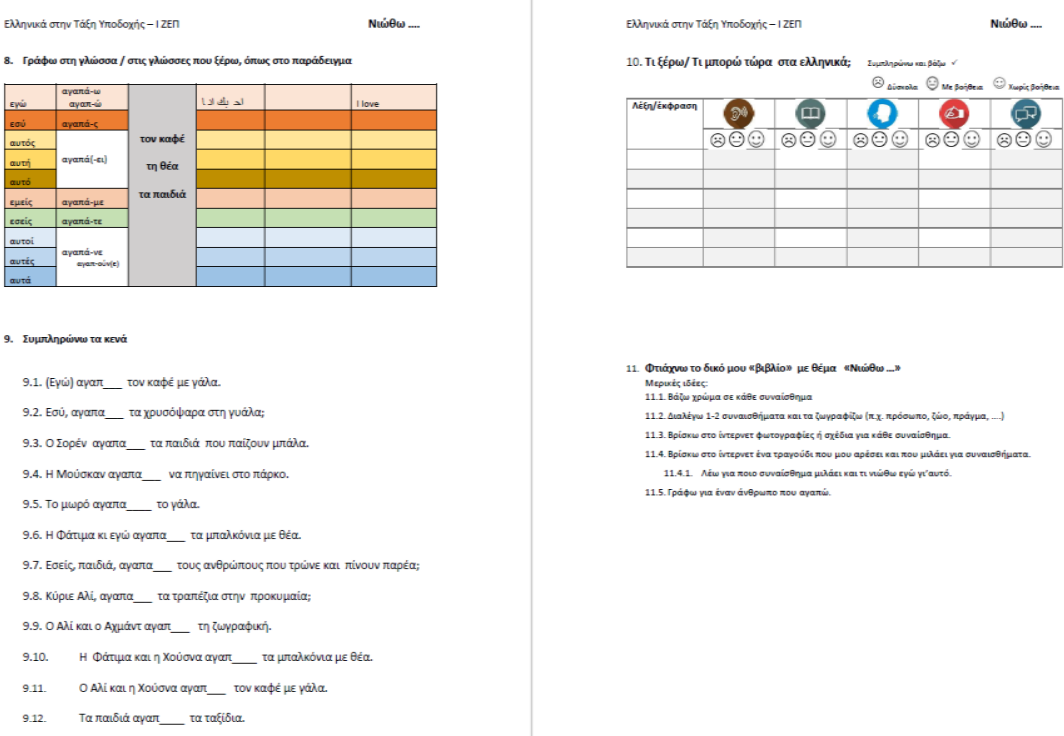

Figure 5. Educational Material, p.p.5-6. (Activities 8-11)

Moreover, further multimodal communicative means, such as pictures (1.), sketches (2.4., 4., 5.1.) and tables (6.,7.,8.) (Figures 3,4,5) were included combining language and visual stimuli in order to support F.A. cognitively, making the educational material more attractive and matching her personal preference on drawing.

Generally, it has been attempted to make the material user-friendly, including e.g. sufficient space for her own responses $(2.4,4 ., 5.2$., etc.) but also viewable with a similar density and quantity of information on each page.

Moreover, the activities were selected in order to allow flexibility in linking them to the following sections, both vocabulary and communication circumstances, as well as grammatical forms (e.g. with a potential section "Mou aresei", suitable for comparative treatment with each other) providing the necessary coherence in this tailor-made curriculum (Howard \& Major, 2004).

Finally, critical analysis was encouraged through student's evaluation of the information of the text/song (5.1., 5.2.), self-assessment (10.) (Ontario Ministry of Education, 2008; Council of Europe, 2014) and self-awareness activities, inviting her to share experiences, thoughts, and feelings in a more or less creative way (2.2., 2.3., 2.4., 5.3., 11.)(Ada, \& Campoy, n.d.; Cummins, 2001). Learner's autonomy and selfregulation of the learning process is the long-term goal (Cummins et al., 2005) of this whole intervention, reflected on this language learning educational work-sheet.

\section{Conclusion}

This study allowed deeper exploration and more systematic analysis of the educational procedure necessary to plan second language teaching material appropriate for adolescents with refugee/migrant background.

Evidently, given all students' superdiversity (Bloch \& Hirsch, 2017), a thorough communicative needs assessment, based -among others- on initial interviews and on multimodal identity texts, is a practice that should be generally used for all minority language students at least, in order to support their unique identity investment in the learning procedure towards bi/multilingual classroom practices, respecting all students' home language(s). 
A tailor-made curriculum and a student-specific syllabus providing differentiated and individualized meaningful learning experiences is necessary (Kaneva, 2012) in order to develop all aspects of language proficiency (Cummins, 2001).

For this purpose, especially in the monoglossic Greek educational system, a teacher even if she/he does not speak students' home languages- can create a multiliterate community (Schwarzer, Haywood \& Lorenzen, 2003). Thus, word walls and cognate charts produced after classroom cooperative work, playful activities (e.g. KamperiTzouriadou \& Pantazi, 2004), displays of photographs or other multilingual realia (newspapers, books, etc.) and multiple other bi/multilingual resources (e.g. internet, versions of songs and other popular art works) brought by students (Celic \& Seltzer, 2011) can be used as an extension of the suggested (6 page work-sheet) educational material on the specific topic.

Furthermore, a project based extension activity of creating every student's 'dual language book" (e.g. $11^{\text {th }}$ activity) or a digital story telling could enhance a multicultural learning community, welcoming student's diversive characteristics at school and connecting the academic community with the broader society, which becomes more inclusive and, hence, democratized.

References

Ada, A. F., \& Campoy, F. I. (n.d.). Authors in the classroom: A transformative education process. Retrieved from http://almaflorada.com/doc/Authors-in-the-classroom.pdf

Androulakis, G., Gkaintartzi, A., Kitsiou, R., \& Tsioli, S. (2016). Parents-schools' communication and Albanian as a heritage language in Greece. Handbook of Research and Practice in Heritage Language Education, 1-18.

Angeli, A. (2016). I provoli kinimatografikis tainias sto plaisio tis ekpaidefsis enilikon. I gnomi didaskonton tin elliniki os deftri/xeni glossa. Diethnes Synedrio gia tin Anoikti kai ex apostaseos ekpaidefsi, 6(1A).

Angeli, A. (2017). I syneisfora tou video stin Ex Apostaseos didaskalia tis Ellinikis os defteris/xenis glossas. Diethnes Synedrio gia tin Anoikti kai ex apostaseos ekpaidefsi, 'O sxediasmos tis mathisis', 9(3A), 120-128.

Antoniou, M. \& Detsoudi, Z. (2004). Liga tragoudia tha sou po. Ethniko kai Kapodistriako Panepistimio Athinon. Kentro Diapolitismikis Agogis. Athina.

Bloch, A., \& Hirsch, S. (2017). The educational experiences of the second generation from refugee backgrounds. Journal of Ethnic and Migration Studies, 43(13), 2131-2148.

Block, K., Cross, S., Riggs, E. and Gibbs, L. (2014). Supporting schools to create an inclusive environment for refugee students. International Journal of Inclusive Education, 18(12), 13371355.

Braun, V., \& Clarke, V. (2006). Using thematic analysis in psychology. Qualitative research in psychology, 3(2), 77-101.

Celic, Ch., and Seltzer, K. (2011). Translanguaging: a CUNY-NYSIEB guide for educators. CUNYNYSIEB, The Graduate Center, The City University of New York

Chumak-Horbatsch, R. (2012). Linguistically appropriate practice. A guide for working with young immigrant children. New York, USA: University of Toronto Press.

Council of Europe (2014). Language Policy Unit -Project LIAM. 25 - Finding out what refugees can already do in the target language and what they need to be able to do. Retrieved from http://rm.coe.int/tool-25-finding-out-what-refugees-can-already-do-in-the-targetlanguag/16807171aa

Cummins, J. (2001). Negotiating Identities: Education for empowerment in a diverse society. 2nd Edition. Los Angeles: California Association for Bilingual Education.

Cummins, J. (2008). BICS and CALP: Empirical and Theoretical Status of the Distinction. In Street, B. V., \& Hornberger, N. H. (Eds.). Encyclopedia of Language and Education, $2^{\text {nd }}$ Edition, Volume 2: Literacy, pp.71-83. New York: Springer Science + Business Media LLC.

Cummins, J. (2009). Pedagogies of choice: challenging coercive relations of power in classrooms and communities. International Journal of Bilingual Education and Bilingualism 12 (3), 261-271

Cummins, J., \& Early, M. (2011). Identity Texts- The collaborative creation of power. Stroke-onTrend: Trendham Book Publishers. 
Cummins, J., Bismilla, V., Chow, P., Cohen, S., Giampapa, F., Leoni, L., ... \& Sastri, P. (2005). ELL students speak for themselves: Identity texts and literacy engagement in multilingual classrooms. Educational Leadership Journal, 63(1), 38-43.

Dryden-Peterson, S. (2015). The educational experiences of refugee children in countries of first asylum. Washington, DC: Migration Policy Institute.

Engelbrecht, P., Savolainen, H., Nel, M., Koskela, T., \& Okkolin, M.-A. (2017). Making meaning of inclusive education: classroom practices in Finnish and South African classrooms, Compare: A Journal of Comparative and International Education, 47:5,684-702

Gkaintartzi, A., Kiliari, A., \& Tsokalidou, R. (2016). Heritage language maintenance and education in the Greek sociolinguistic context: Albanian immigrant parents' views. Cogent Education, $3(1), 1155259$

Hornberger, N. (2004). The continua of biliteracy and the bilingual educator: Educational linguistics in practice. Bilingual Education and Bilingualism, 7(2\&3), 155-171.

Howard, J., \& Major, J. (2004). Guidelines for designing effective English language teaching materials. The TESOLANZ Journal, 12, 50-58. http://www.paaljapan.org/resources/proceedings/PAAL9/pdf/Howard.pdf

Kamperi-Tzouriadou, E. \& Pantazi, S. (2004). Paidagogika paixnidia. T. A’ . Ioannina. Retrieved from https://repository.edull1.gr/edull1/retrieve/1409/256.

Kaneva, D. (2012). Teaching and learning in diverse school contexts: the journeys of three newly arrived students. In D. Mallows (Ed.), Innovations in English language teaching for migrants and refugees (pp. 49-64). London, UK: British Council.

Kompiadou, E., \& Tsokalidou, R. (2014). Identity texts: their meaning for their writers and readers. p.p.48-51. Polydromo (7).

Ontario Ministry of Education (2008). Supporting English language Learners with limited Prior Knowledge - A practical Guide for Ontario Educators, Grades 3-12. Toronto: Ontario Ministry of Education

Rodgers, T. S. (2009). The methodology of foreign language teaching: Methods, approaches, principles. In K., Knapp \& G. Antos (Eds.), Handbook of foreign language communication and learning (pp. 341-373). Berlin: Mouton de Gruyter

S.C.S.R.C.-Scientific Committee for the Support of Refugee Children (2017). Refugee Education Project. A. Assessment Report on the Integration Project of Refugee Children in Education. $b$. Proposals for the education of refugee children during the 2017-18 School Year. Athens: Ministry of Education Research \& Religious Affairs.

Schwarzer, D., Haywood, A., \& Lorenzen, C. (2003). Fostering multiliteracy in a linguistically diverse classroom. Language Arts, 80(6), 453-460.

Taylor, S. J., Bogdan, R., \& DeVault, M. (2015). Introduction to qualitative research methods: A guidebook and resource. John Wiley \& Sons.

YPETH (Ypourgeio Paideias Erevnas kai Thriskevmaton) (2018). Anoikto Programma Spoudon gia ti didaskalia tis ellinikis glossas stis Taxeis Ypodoxis (T.Y.) I ZEP Defterovathmias Ekpaidefsis (A.P.660/GD4/3.1.2018). Retrieved 20.3.2018 from http://www.iep.edu.gr/images/IEP/EPISTIMONIKI_YPIRESIA/Epist_Monades/A_Kyklos/Di apolitismiki/2018/2018-01-18 APS TY abathmia.pdf 